\title{
«Felicidad, bienestar, gloria y honor»; la imagen pública que Samuel ha-Leví proyectó en la Sinagoga del Tránsito
}

\author{
Daniel Muñoz Garrido* \\ CSOC, Ben-Gurion University of the Negev
}

Samuel ben Meír ha-Leví Abulafia es un personaje destacado de la historia de los judíos en los reinos peninsulares. Ejerció como tesorero del rey castellano Pedro I y fue el fundador de la Sinagoga del Tránsito. La fundación de una sinagoga de tal tamaño, belleza y lujo debió suponer para Samuel ha-Leví todo un logro político y personal, que seguramente fue percibido como una proeza por los vecinos de la aljama toledana. En el contexto del complejo sistema de mecenazgo medieval las fundaciones buscaban ser símbolos de nobleza y prestigio dentro del escenario de poder de la sociedad del momento. El análisis de los símbolos de los que se sirvió y rodeó Samuel ha-Leví en su sinagoga esbozan un retrato, no solo de como él se veía a sí mismo, sino también de como él quiso ser percibido y recordado. Este artículo busca analizar la imagen pública que Samuel quiso proyectar, basada en el análisis de la sinagoga y sus textos epigráficos.

Palabras Clave: Judíos; Toledo; arte religioso; mecenazgo medieval; linaje medieval; nobleza.

"Happiness, Well-being, Glory and Honor," the Public Image that Samuel ha-Levi Showed through the Synagogue of El Tránsito.- Samuel ben Meir ha-Levi Abulafia is a prominent figure in the history of Iberian Jews. He acted as the treasurer of Castilian king Pedro 1st, and funded the Toledo synagogue known as Synagogue of the Transito. The foundation of a building of such size, beauty and luxury must have meant one of Samuel ha-Levi's major personal and political achievements, and must have been perceived as a main deed by his contemporary fellow Jews. In the context of the complex medieval patronage system, foundations were meant to symbolize nobility and prestige within the power scene of society. The analysis of the symbols utilized by Samuel ha-Levi in the synagogue he founded shows the way in which he viewed himself, as well as the way he wanted to be

\footnotetext{
"danielmugarrido@gmail.com
} 
viewed and remembered. This essay, based in the analysis of the synagogue and its epigraphy, intends to examine the public image that Samuel ha-Levi attempted to project.

KeYwords: Jews; Toledo; Religious Art; Medieval Patronage; Medieval Lineage; Nobility.

\section{PResentación}

Samuel ben Meír ha-Leví Abulafia es uno de los personajes más relevantes de la historia judía en los reinos cristianos de la Península Ibérica, pues llegó a ser una de las personas más influyentes en la corte del rey castellano Pedro I y un destacado miembro de la escena política de la Castilla del siglo XIV.

Perteneciente a la familia ha-Leví Abulafia, de tanto arraigo en Toledo, su padre, Meír ha-Leví, ejerció como líder comunitario ${ }^{1}$. Aunque no se tienen muchas más noticias de su vida familiar, parece que tuvo al menos un hijo, llamado Yuçaf, mencionado en la carta de perdón que otorgó el rey en Toledo en $1355^{2}$, y otro llamado Todros ${ }^{3}$. Samuel ha-Leví sirvió en primer lugar como administrador para Alfonso de Alburquerque y, de su mano, entró al servicio del rey, llegando a desempeñar un papel casi omnipotente en la corte durante un periodo de diez años ${ }^{4}$.

Durante estos años, su principal ocupación fue reorganizar la hacienda castellana ya que los recaudadores, aprovechando la joven edad que

${ }^{1}$ El epitafio de la tumba de Samuel ha-Leví dice que su padre fue R. Meír ha-Leví y en la placa fundacional de la sinagoga se menciona a este como líder comunitario. La inscripción está muy deteriorada y por esta razón en el pasado se dio una lectura diferente a este nombre. De esta forma surgió la figura del arquitecto Don Meír Abdeli. Este personaje nació en la obra de José AMADOR DE LOS Ríos, Toledo pintoresca, publicada en 1845. El error fue repetido por muchos autores posteriores, debido a la amplia difusión que tuvo la obra fosilizándose como verdadero, llegando incluso a estar presente en estudios recientes; Santiago Palomero Plaza, Historia de la Sinagoga de Samuel ha Leví y del Museo Sefardí de Toledo (Madrid 2007) págs. 90-92.

2 Pilar León Tello, Judíos de Toledo I (Madrid 1979) pág. 137.

${ }^{3}$ Franciso Cantera Burgos y José M. ${ }^{a}$ Millás Vallicrosa (Las inscripciones hebraicas de España [Madrid 1956] págs. 367-368) identifican un sello judío del British Museum, que perteneció a Todros ha-Leví, como el de un posible hijo de Samuel ha-Leví.

${ }^{4}$ Julio Valdeón Baruque, El Chivo Expiatorio: judíos, revueltas y vida cotidiana en la Edad Media (Valladolid 2000) pág. 31. 
tenía Pedro I cuando llegó al trono, no habían entregado la totalidad de los impuestos incautados. Samuel tras investigar a los recaudadores, les hizo devolver el dinero desfalcado a las arcas reales que, en la mayoría de los casos, ascendía a la mitad de las cantidades expresadas en las escrituras $^{5}$. Sus ocupaciones no se limitaron a las finanzas, desempeñó funciones de tipo judicial al presidir, junto a un juez cristiano, el tribunal real que dictaminó acerca de si el obispo de Córdoba estaba obligado a pagar impuestos ${ }^{6}$. También actuó como diplomático, cuando en 1358 acudió en misión diplomática a Portugal para la firma del tratado de Évora? La figura de Samuel estuvo estrechamente ligada a la figura de Pedro I. La relación que existió entre los dos fue muy fructífera para ambos. La gestión realizada por Samuel ha-Leví fortaleció la figura del rey ante la nobleza rebelde y Samuel ha-Leví llegó a ser el judío más influyente y poderoso de su época de manos del monarca.

A pesar de la relevancia histórica, Samuel ha-Leví es recordado, especialmente, por ser el fundador de la llamada Sinagoga del Tránsito. En la construcción de este edificio no escatimó en recursos y se sirvió de inscripciones y símbolos para proyectar una imagen pública que permaneciera en el tiempo.

A lo largo de los siglos XIV y XV la nobleza castellana experimentó fuertes cambios que la transformaron en un nuevo grupo oligárquico, que ha sido denominado «nueva nobleza». Durante estos siglos se produjo una intensa renovación nobiliaria. Muchos viejos linajes castellanos perdieron influencia política y económica, dando paso a otros más modernos con ascendencias menos esclarecidas que ocuparon los puestos políticos más altos ${ }^{8}$. Los linajes nobiliarios del final de la Edad Media proyectaron su poder en la ciudad. En este contexto urbano desplegaron todo un aparato simbólico que buscaba afianzar la influencia de un linaje en el ámbito de la ciudad. El origen ilustre del linaje, las relaciones y cercanía al rey, las posesiones dentro de la ciudad, la casa señorial como emblema de

\footnotetext{
${ }^{5}$ VAldeón BARUQue, El Chivo Expiatorio, pág. 31.

${ }^{6}$ Yitzhak BAER, Historia de los judíos en la España cristiana (Barcelona 1998) pág. 405.

${ }^{7}$ Valdeón Baruque, El Chivo Expiatorio, pág. 31.

${ }^{8}$ Salvador DE Moxó, Feudalismo, señorío y nobleza en la Castilla medieval (Madrid 2000) págs. 312 y 343.
} 
la dinastía familiar, el honor, las fundaciones y donaciones piadosas, la pompa fúnebre y la memoria de los difuntos son algunos de los elementos que conformaron este aparato simbólico?.

La sinagoga de Samuel ha-Leví cobra nuevo sentido al ser interpretada en el marco de este contexto nobiliario, en el que las fundaciones y donaciones personales buscaban ser símbolos de nobleza y prestigio dentro del escenario de poder de la sociedad noble del momento. El análisis de los símbolos de los que se sirvió y rodeó Samuel esboza un retrato, no solo de como él se veía a sí mismo, sino también de como él quiso ser percibido y recordado. El poder económico y político, la sabiduría, la importancia y calidad del linaje de Samuel ha-Leví son elementos presentes intencionadamente en la decoración de la sinagoga que nos muestran cual fue la imagen pública que Samuel construyó para sí. Los poderosos siempre se han servido de la arquitectura para manifestar su presencia y los poderes políticos han buscado justificarse ante su comunidad a través de proyectos artísticos a los que incorporan mensajes ideológicos que se sustentan en un pasado glorioso, ya sea este verídico, creado o reelaborado ${ }^{10}$.

En este artículo presento una propuesta sobre cómo Samuel ha-Leví se percibió a sí mismo, y como quiso que los demás lo recordaran, basada en el análisis de la sinagoga que fundó y en el de los textos que la decoran. No voy a centrarme en hechos históricos, sino en cómo las tradiciones literarias, los imaginarios y los símbolos contribuyen a construir las representaciones de los individuos públicos.

\section{SAMUel: Poder ECONÓMICO y POLÍTICO}

La fundación de una sinagoga de tal tamaño, belleza y lujo, junto a la casa señorial que se encontraba a uno de los lados de la sinagoga, debió suponer para Samuel ha-Leví todo un logro personal y político, que se-

\footnotetext{
${ }^{9}$ Juan Ramón Palencia Herrejón, «Elementos simbólicos de poder de la nobleza urbana en Castilla: los Ayala de Toledo al final del Medioevo», En la España Medieval 18 (1995) págs. 163-179.

${ }^{10}$ José Miguel Puerta Vílchez, Los códigos de utopía de la Alhambra de Granada (Granada 1990) págs. 80-81.
} 
guramente fue percibido como una proeza por los vecinos de la aljama toledana, de la que él era cabeza. La sinagoga, más allá de su finalidad como lugar de culto, tuvo también un sentido simbólico y propagandístico. Tras la fundación de un edificio de estas características también estaba la intención de que la gloria de su fundador, Samuel ha-Leví, perdurara en el tiempo y fuera transmitida a las generaciones venideras. Para tal fin fueron colocadas las dos grandes placas fundacionales y otras dos placas escudadas, situadas a ambos lados del hejal, que dejarían, en la historia, constancia de la autoría y generosidad de Samuel al fundar la sinagoga.

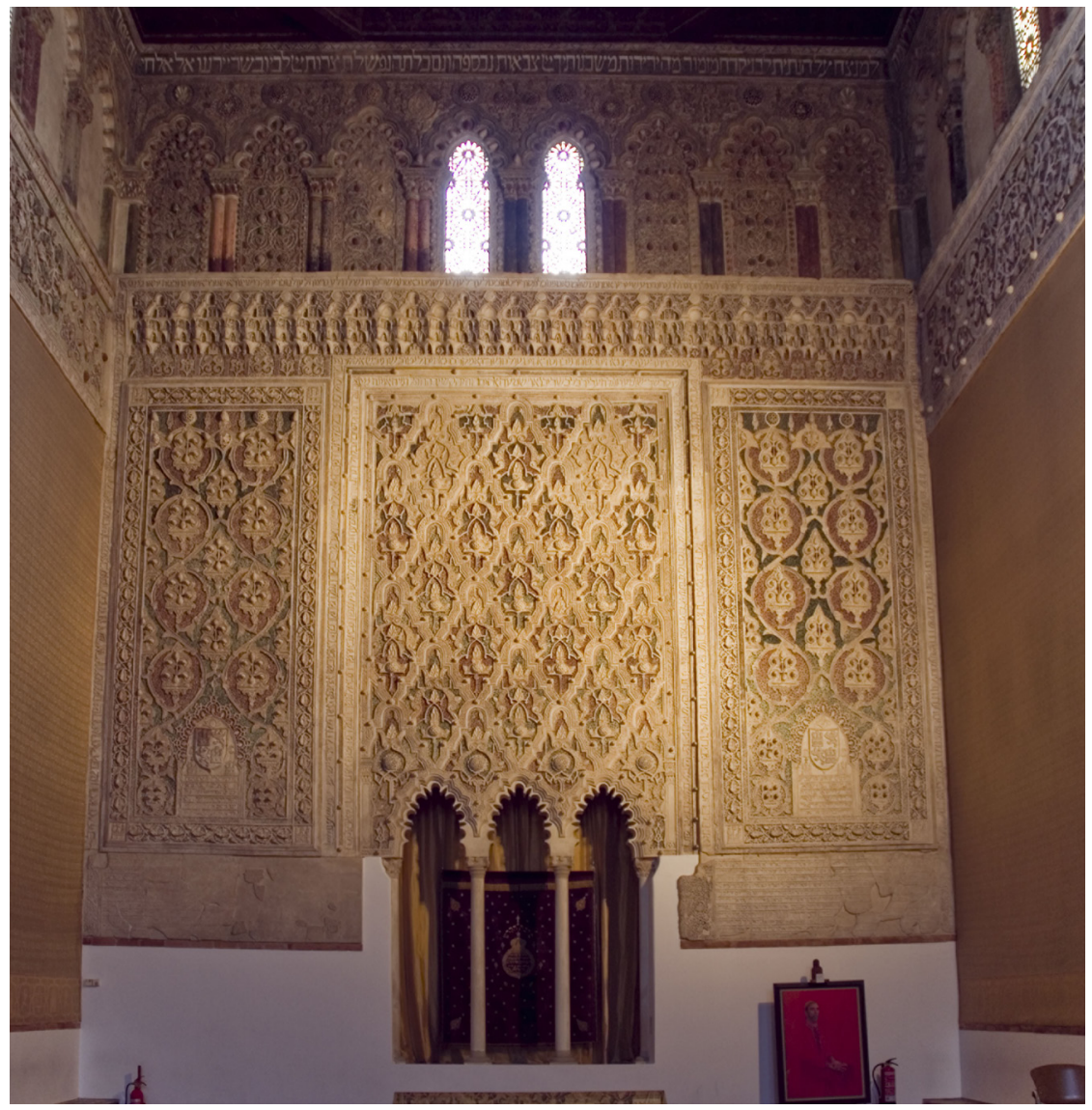

Fig. 1. Vista general del hejal de la sinagoga de Tránsito. 
La placa escudada del lado izquierdo del hejal da testimonio de esta generosidad y del poderío económico de Samuel al construir una casa señorial y una sinagoga de la siguiente manera ostentosa:

Contemplad el santuario que ha sido consagrado en Israel / y la casa que ha edificado Semuel / y la torre de madera para la lectura de la ley en el centro de ella, / y los rollos y las coronas del mismo dedicadas a Él, / y sus páteras y sus lámparas para la iluminación ${ }^{11}$.

La inscripción deja constancia del poder económico de Samuel que no solo es capaz de construir la casa ${ }^{12}$ y la sinagoga sino que además puede dotarla de todos los muebles y objetos para el culto. Las sinagogas solían tardar tiempo en acumular todos estos objetos que eran donados, ya fuera en vida o tras la muerte, por las mujeres y los hombres de la comunidad. La generosidad entendida como una muestra de magnificencia formaba parte de la iconografía del poder real en la que el mecenazgo artístico era vinculado a la labor gubernativa que reflejaba la virtus del príncipe o monarca ${ }^{13}$. La inscripción de la placa escudada del lado izquierdo nos muestra, siguiendo la iconografía del poder de la época, a Samuel como un líder magnánimo y con virtus.

Las relaciones y la cercanía al rey tienen especial importancia en el aparato simbólico que la nobleza castellana desplegó en las ciudades. La cercanía al rey era sinónimo de poder político. Samuel como almojarife de Pedro I gozaba de esas relaciones cercanas y, como era de esperar, no dejó de mostrarlas públicamente como se puede ver en la placa fundacional derecha de la sinagoga:

Halló gracia y favor a los ojos de la gran águila, grande de alas, hombre de guerra y hombre de batalla, cayó / su terror sobre los pueblos, su

\footnotetext{
${ }^{11}$ Francisco Cantera Burgos, Sinagogas Españolas (Madrid 1984) pág. 98.

${ }^{12}$ Samuel ha-Leví, además de la sinagoga, también construyó una gran casa señorial junto a ella. Ambas construcciones deben entenderse como partes que conforman la simbología del poder que Samuel utilizó dentro de la aljama y de la ciudad de Toledo. De esta gran casa que Samuel construyó solo queda parte de la planta sótano que, hoy en día, está integrada en el Museo del Greco de Toledo.

${ }^{13}$ Olga Pérez Monzón, «Iconografía y poder real en Castilla: las imágenes de Alfonso VIII», Anuario del Departamento de Historia y Teoría del Arte 14 (2002) págs. 19-41: $19-22$.
} 
nombre es grande entre las naciones, el gran rey, nuestro señor y dueño, El REY DON PEDRO ${ }^{14}$.

Hallar gracia a los ojos de la gran águila, el rey don Pedro, significa, ni más ni menos, que Samuel ostenta poder y ocupa un lugar destacado en la escala aristocrática. La sinagoga está dirigida, naturalmente, a un público judío y la inscripción está en hebreo lo que nos muestra que este atributo, el estatus dentro de un sistema aristocrático cristiano en el que, en teoría, los judíos están excluidos, ha traspasado una frontera cultural. Es decir, la posición que se ocupa dentro de la corte, es también un atributo a reconocer y elogiar para la élite judía de la Castilla del siglo XIV, dentro de una sociedad estamental donde la nobleza ocupa el más alto nivel.

\section{SAMUEL: SABiduría MÁS ALLÁ DE LO NATURAL}

El poder no fue el único atributo con el que Samuel construyó su identidad pública. La sabiduría parece ser otro de los elementos con los que Samuel quiso ser relacionado. Son diversos las crónicas y los textos medievales los que presentan la sapientia como una de las virtudes que debe poseer un monarca. Toda esta literatura evidencia que la sabiduría fue entendida durante la Edad Media como un elemento central dentro de la iconografía real $^{15}$.

Las tradiciones bíblica y coránica representan al rey Salomón como el rey constructor. Es evidente que este epíteto le viene dado por la construcción del Templo de Jerusalén, que es la razón por la que diferentes reyes y califas han buscado, a través de la arquitectura, la equiparación con la figura de Salomón. Un buen ejemplo lo encontramos en la poesía epigráfica de la Alhambra donde el soberano como constructor es una constante. En un poema que decora el mirador de Lindaraja, el sultán es comparado con el rey Salomón. La comparación se realiza mediante la equiparación entre una alberca o fuente cercana al mirador con el suelo de cristal que, según la tradición islámica, construyó Salomón en uno de sus palacios (sura 27,44). Según

${ }^{14}$ Cecil Roth, «Las inscripciones históricas de la Sinagoga del Tránsito de Toledo», Sefarad 8:1 (1948) págs. 19-22.

${ }^{15}$ Pérez Monzón, «Iconografía y poder real en Castilla», págs. 25-26. 
los comentaristas, el rey Salomón se valió de este suelo que asemejaba ser de agua para que la reina de Saba tuviese que recogerse la falda para no mojársela. Con esta argucia, Salomón pudo ver las piernas de la reina y comprobar si, como se decía, tenía piernas velludas y pies de cabra ${ }^{16}$.

Sin embargo, en el caso de la Sinagoga del Tránsito, los referentes elegidos para comparar a Samuel y a la sinagoga no son el rey Salomón y el Templo de Jerusalén, como podría derivarse de la belleza y tamaño del edificio pues, en este caso, la placa escudada del lado izquierdo del hejal, establece una comparación con el Tabernáculo y la figura de Besalel:

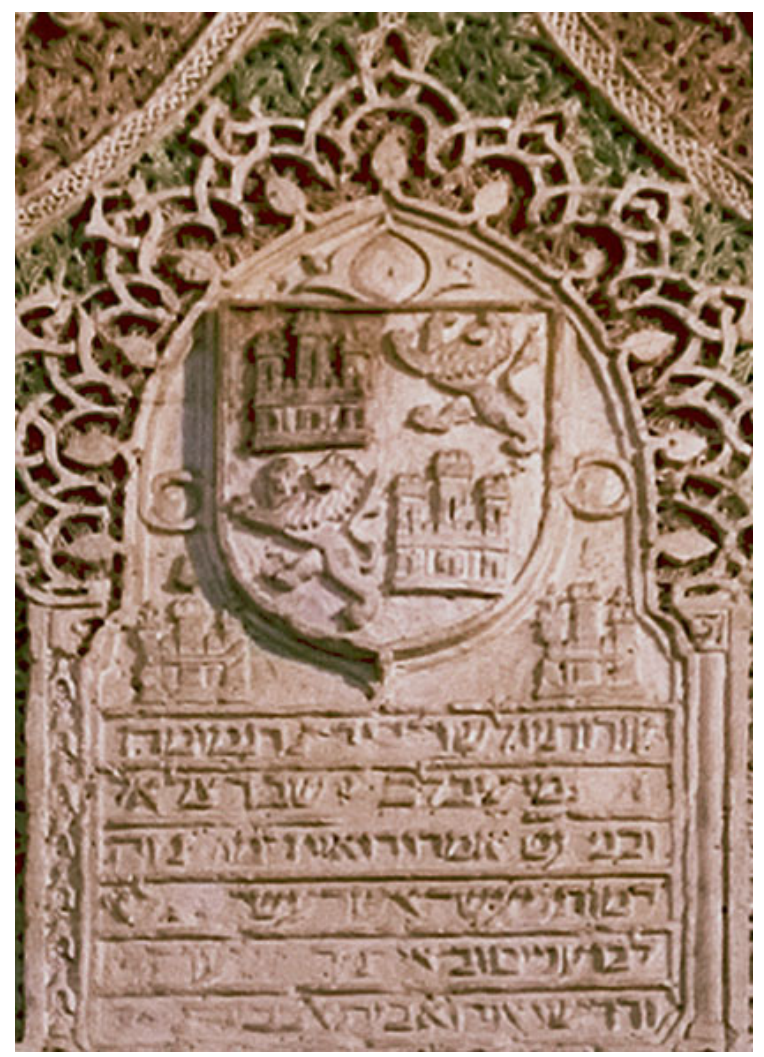

Fig. 2. Placa escudada situada en el lado izquierdo del hejal de la Sinagoga del Tránsito.

${ }^{16}$ Puerta Vílchez, Los códigos de utopía, págs. 124-125. 
La inscripción dice así:

Y sus atrios para quienes están atentos a la Ley perfecta, / y su casa de asiento para cuantos se sientan a la sombra de Él, / de suerte que casi hayan de decir quienes lo vean: La traza de este [Templo] / es cual la traza de la obra que ejecutó Besalel ${ }^{17}$.

Con esta inscripción Samuel es equiparado con Besalel y la sinagoga con el Tabernáculo. En algunas tradiciones judías, Besalel es presentado como un paradigma de la sabiduría ya que su saber tiene un origen divino siguiendo Ex 31,2-5:

"Mira, he llamado nominalmente a Besalel, hijo de Uri, hijo de Hur, de la tribu de Judá, y le he henchido del espíritu de Elohim, en habilidad, en inteligencia, en saber, en toda tarea; para idear proyectos artísticos".

La atribución a Besalel de una sabiduría especial debía formar parte del imaginario colectivo judío, ya que está recogida en diferentes tradiciones literarias y son diversas las fuentes que han especulado sobre el origen de la sabiduría de Besalel las que han transmitido a lo largo del tiempo este imaginario. Como por ejemplo el Zóhar donde la figura de Besalel, su sabiduría y la construcción del Tabernáculo son temas desarrollados en algunas de sus secciones, especialmente, en Terumá y Pecudé. Incluso, ya Filón de Alejandría (ca. 20 a.e.c - ca. 50 e.c.) utilizó a Besalel como ejemplo del conocimiento puro en II Gigantes 22-23:

El nombre «espíritu de Dios», entiéndese en dos sentidos. Según uno de ellos, designa el aire que fluye desde la tierra, es decir, el tercer elemento, que se mueve sobre el agua, por lo que en el relato de la creación dice Moisés: «El espíritu de Dios flotaba sobre las aguas» (Gn 1,2); lo que se explica porque, siendo más liviano, el aire, se eleva y flota arriba teniendo al agua como base; según el otro, se aplica al conocimiento puro del que, lógicamente, todo hombre sabio participa. El legislador lo señala, cuando dice, refiriéndose al autor y artífice de las sagradas obras: «Llamó Dios a Besalel, y lo llenó del Divino espíritu, de sabiduría, de entendimiento, de ciencia, para que discerniese en toda obra». (Ex 31,2-3) Con lo dicho ha quedado descrito sucintamente lo que es el espíritu de Dios ${ }^{18}$.

${ }^{17}$ Cantera Burgos, Sinagogas Españolas, pág. 98.

${ }^{18}$ Filón de Alejandría, Obras completas. Vol. 1, trad. J. M. Triviño (Buenos Aires 1976) pág. 63. 
La referencia a Besalel y al origen de su sabiduría que posiblemente fuera más conocida la encontramos en el Tratado Berajot 55a del Talmud de Babilonia donde se explica que se llama así por su sabiduría, pues su nombre significa 'en la sombra de Dios' (בצלאל). El texto continúa con la narración de una historia que argumenta el sentido de su nombre, y reflexiona sobre el origen de su sabiduría:

Dijo el rabí Shemuel bar Najmaní en nombre del rabí Iojanán: Besalel se llama así por su sabiduría. (Be zel el, en la sombra de Dios) Cuando el santo, bendito sea, le dijo a Moisés: ve a decir a Besalel que me haga un tabernáculo, una arca y utensilios, Moisés se lo transmitió al revés: Haz un arca, utensilios y un tabernáculo.- Moisés, maestro nuestro- le contestó [Besalel]-, en todas partes se acostumbra que el hombre construya primero la casa y luego traiga los utensilios; y tú me dices: haz un arca, utensilios y un tabernáculo. ¿Dónde pondré los utensilios que haga? ¿No te habrá dicho el santo, bendito sea: haz un tabernáculo, un arca y utensilios?- Tú habrás estado- respondió [Moisés] en la sombra de Dios; por eso lo sabes.

Besalel sabía combinar las letras con las que se creó el cielo y la tierra, porque aquí dice [...] y lo ha llenado del espíritu de Dios, en sabiduría, en inteligencia en ciencia [...] (Ex 25,31), y allí dice: el Señor con sabiduría fundó la tierra; afirmó los cielos con inteligencia ( $\mathrm{Pv} 3,19)$. Y con su ciencia los abismos fueron divididos (Pv 3,20).

A través de la inscripción de la placa escudada izquierda, donde se equipara a Samuel y a la sinagoga con Besalel y el Tabernáculo, se quiere dotar a Samuel de la sabiduría de Besalel, virtud que le es inherente, según lo expuesto en la obra de Filón de Alejandría, el Talmud de Babilonia y el Zóhar. Samuel ha-Leví buscó, intencionadamente, ser comprado con Besalel para atribuirse de esta forma la posesión de un elevado grado de sabiduría.

Tras analizar la decoración de la Sinagoga del Tránsito ${ }^{19}$ he podido comprobar que la figura de Besalel y el conocimiento que tenía de los números con los que se creó el cielo y la tierra, ocupan un importante lugar en la simbología que esconde la decoración de la Sinagoga que está basada en el Génesis y más concretamente en la separación del cie-

${ }^{19}$ Daniel MuÑoz Garrido, «La creación del mundo en el arte medieval: La Sinagoga del Tránsito», 'Ilu. Revista de Ciencias de las Religiones 15 (2010) págs. 129-146. 
lo y de la tierra. Por otro lado, el texto del Tratado Berajot 55a y las cualidades que en él se atribuyen a Besalel, resultarían, en mi opinión, muy fácilmente interpretables desde una óptica cabalista por un iniciado, ya que la relación entre el constructor del Tabernáculo y la creación del cielo y de la tierra no es ajena a la tradición mística de la cábala ibérica. Sin ir más lejos, Besalel es mencionado en el Zóhar en 39 ocasiones. La importancia que esta obra otorga a la figura de Besalel y a su sabiduría me han hecho sospechar que la simbología desplegada en la Sinagoga del Tránsito podría tener un nivel de lectura más profundo, dirigido a un público iniciado en la cábala. Esta posibilidad trae consigo una cuestión sobre sus fundadores: ¿Samuel ha-Leví y su padre formaron parte de algún circulo cabalístico? El trasfondo cabalístico de la decoración de la sinagoga y la posible iniciación de Samuel en la Cábala son cuestiones que necesitan de más estudio y sobre las que me encuentro trabajando actualmente.

3. Samuel: «ES la Fortaleza de la torRe igual a la CUAL, DeSDE EL DÍA DEL DESTIERRO DE ARIEL, NO HA SURGIDO NADIE EN ISRAEL»

Otro elemento presente en la decoración de la sinagoga es el linaje. Para la sociedad hispano medieval la nobleza y el linaje, ya fuera este real o inventado, fueron de gran importancia. Samuel ha-Leví descendía de una influyente familia, pertenecía a la élite cultural judía y se desenvolvía en ambientes cortesanos. El linaje de Samuel debía dotarle de una nobleza que justificara su estatus social y debía estar expuesto con claridad en la las placas fundacionales de la sinagoga; vid. fig. 1 supra.

El análisis de este texto resulta clave para entender cómo ha-Leví quería ser percibido y recordado por sus correligionarios. En dicha inscripción podemos apreciar que Samuel ha-Leví es representado como un príncipe en el exilio que cuida de su pueblo, y para ello se alude en varias ocasiones a la nobleza de su linaje entre la diáspora de Israel:

Suscitó [Dios] entre nosotros jueces y príncipes para salvarnos de la mano de / enemigos y opresores. Aun cuando no hay rey en Israel, no nos ha dejado sin un redentor (Rut 4,14). Él es la fortaleza de la torre igual a la cual, desde el día del destierro de Ariel, no ha surgido nadie en Israel: de 
la cadena / del linaje, noble entre los nobles del país uno de sus príncipes y poderosos que se mantienen en la brecha; la rueda del carro de la grandeza, base del imperio y del poder, para fama y gloria y alabanza / su nombre es conocido en Israel. Desde que se hallaba en su tierra se mantuvo ante los reyes $(\mathrm{Pv} 22,29)$ para estar en la brecha (Sal 106,23) y busca el bien de su pueblo (Est 10,3) cabeza de la cautividad de Ariel y escogido de los príncipes, corona / de verdadera gracia y grande entre los judíos ${ }^{20}$.

La inscripción continua más adelante haciendo una atrevida relación entre la casa familiar de Samuel, los ha-Leví, y la monarquía de Israel:

Él es el pilar derecho sobre el cual se basa la Casa de Levi y la Casa de Israel. ¿Quién puede enumerar sus alabanzas y sus cualidades, y sus hechos / quien puede contar y quien puede llegar al fin de sus laúdes? Él es la diadema del imperio y del tesoro de la gloria que estuvo al comienzo de la serie [linaje], príncipe entre los príncipes del cuerpo levítico, Samuel ha Levi ${ }^{21}$.

Con este texto, Samuel ha-Leví reafirma su linaje levítico para mostrarse como un príncipe descendiente de la realeza de Israel. La placa fundacional contiene otra referencia similar implícita en una de las alabanzas que la inscripción realiza a Pedro I. En la inscripción el rey castellano es llamado «la gran águila, grande de alas». Esta comparación es una cita bíblica tomada de Ez 17,3. En este pasaje, la gran águila es Nabucodonosor que ha tomado a los reyes y príncipes de Jerusalén y los ha llevado a Babilonia:

El águila, de grandes alas, de largas plumas remeras, cubierta de plumaje de diversos colores, vino al Líbano y cogió la copa de un cedro, arranco la punta de sus ramas, la llevo hacia país de comercio, y la colocó en una ciudad de mercaderes (Ez 17,3-4) [...] He aquí que ha venido el rey de Babilonia a Jerusalén y ha tomado a su rey a sus príncipes y los ha transportado a Babilonia (Ez 17,12-13).

De esta manera, a través de este paralelismo y de la alabanza a Pedro I: «Halló gracia y favor a los ojos de la gran águila, grande de alas», Samuel es presentado, de manera reiterativa, como un príncipe en la diáspora descendiente de la realeza de Israel y de la élite cultural llevada a Babilonia por Nabucodonosor.

${ }^{20}$ Rотн, «Las inscripciones históricas», págs. 19-22.

${ }^{21}$ Rотн, «Las inscripciones históricas», págs. 19-22. 
Otro elemento que parece estar relacionado con el linaje de Samuel ha-Leví lo encontramos en la parte superior de la sala de oración donde transcurre una inscripción árabe, en letra cúfica entrelazada, que recorre toda la base de la techumbre del edificio. La inscripción es similar a otras inscripciones reiterativas que aparecen con frecuencia en la arquitectura islámica. Está formada por un bloque de cuatro palabras unidas por la conjunción copulativa wa (اليمن والسـلامة والعزة والكرامة). El bloque está compuesto por las palabras al-Yumn wa-l-Salāma wal-'izza wa-l-Karāma, cuya traducción es: 'Felicidad, bienestar, gloria y honor' ${ }^{22}$.

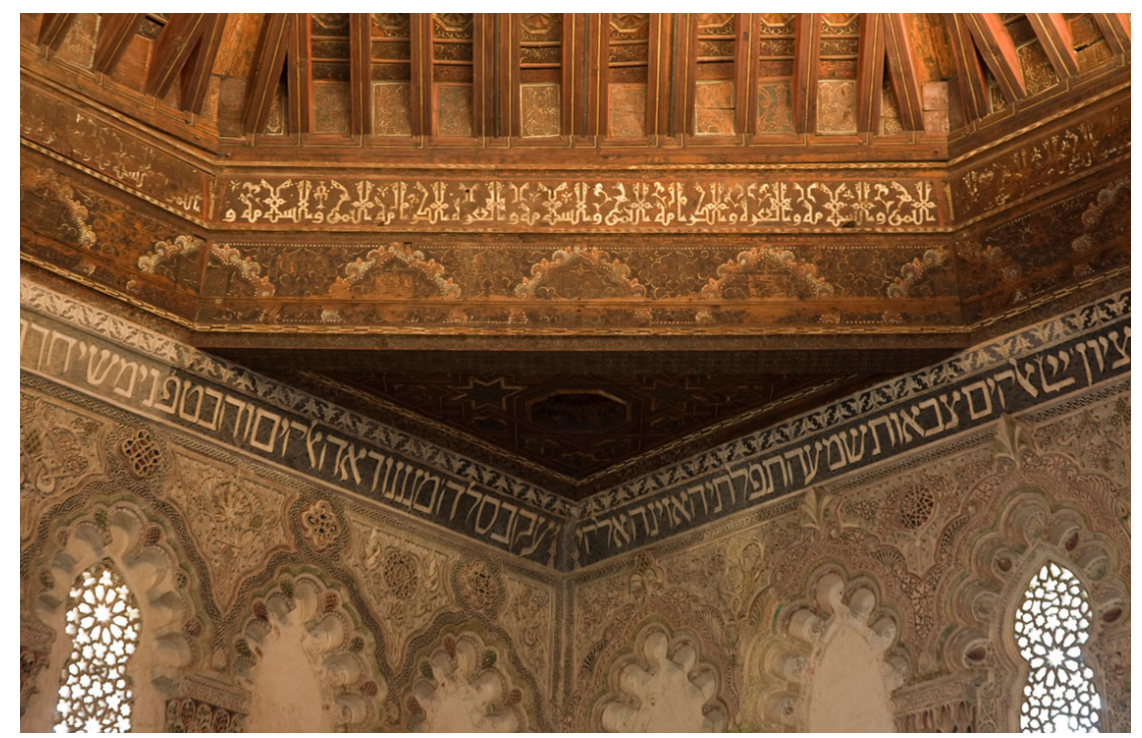

Fig. 3. Inscripción árabe que recorre toda la base de la techumbre de la sinagoga.

Si analizamos la inscripción a través de la importancia que el linaje y la nobleza tenían en la época, podemos apreciar que esos cuatro conceptos no son epítetos relacionados con Dios, sino que parecen más bien, y salvando las distancias, un lema regio, como los que suelen aparecer en algunos escudos nobiliarios. La felicidad, la gloria y el honor son conceptos abs-

${ }^{22}$ Agradezco al Dr. Fco. Javier Aguirre SÁDABA, catedrático de Estudios Árabes e Islámicos de la Universidad de Almería, su inestimable ayuda y la generosidad con la que transcribió y tradujo esta inscripción. 
tractos vinculados al poder. Estos términos, junto a otros, son utilizados en la epigrafía de la Alhambra para elogiar al sultán ${ }^{23}$. Es interesante mencionar que en la decoración del palacio nazarí existen otro tipo de brevísimas inscripciones que expresan conceptos como «salud», «bienestar», «dicha perpetua»y «felicidad», que parecen demandar dichos bienes para sus moradores $^{24}$. La estructura reiterativa de estas inscripciones ha hecho sugerir al profesor Emilio de Santiago que existe una relación con los mantras, ya que a fuerza de repetición se busca conseguir hacer realidad el contenido de la inscripción, gracias al valor mágico-religioso de la palabra escrita ${ }^{25}$.

Bajo la inscripción árabe transcurre un friso decorativo formado por escudos pintados. Estos escudos, rodeados por guirnaldas, que están pintados en la base de la techumbre mudéjar, se encuentran casi borrados por el paso del tiempo y el deterioro de la pintura. Por esta razón es difícil identificarlos pero es muy posible que pertenecieran a Samuel ha-Leví y que formaran, junto al lema en árabe, un conjunto decorativo heráldico. En la sinagoga, además del escudo de Castilla y León, podemos encontrar otro escudo formado por un castillo de tres torres muy similar a una de las figuras del escudo de Pedro I. Era usual que las comunidades judías insertaran en la decoración de las sinagogas el escudo del rey como muestra de fidelidad ${ }^{26}$. La similitud entre los dos escudos que encontramos en la Sinagoga del Tránsito es clara y por ello es fácil atribuir este escudo al rey castellano. Pero, este escudo cuenta con dos flores de lis sobre las torres del castillo y perteneció al almojarife del rey y patrocinador de la sinagoga, Samuel ha-Leví. Ya en 1973, Cantera Burgos sugirió que este escudo, formado por un castillo de tres torres, que muestra una flor de lis sobre cada una de las torres laterales, podría haber pertenecido a Samuel ${ }^{27}$, y con anterioridad, Baer también había identificado este escudo como el de Samuel ha-Leví, apoyándose en un texto histórico. El documen-

${ }^{23}$ Puerta Vílchez, Los códigos de utopía, págs. 86-87.

${ }^{24}$ Puerta Vílchez, Los códigos de utopía, pág. 102.

${ }^{25}$ Puerta Vílchez, Los códigos de utopía, pág. 102.

${ }^{26}$ Isidro BAngo ToRviso, «Judíos, moros y cristianos bajo la autoridad del rey», Memoria de Sefarad (Madrid 2002) págs. 259-265: 263.

${ }^{27}$ Francisco Cantera Burgos, Sinagogas de Toledo, Segovia y Córdoba (Madrid 1973) pág. 64. 
to usado por Baer, fechado el 28 de abril de $1354^{28}$, describe el escudo de Samuel ha-Leví, que había sido estampado en un documento:

[...] avía figura en medio de un castiello e de la una parte e de la otra del dicho castiello estaban figuras de dos aguilas e las de enderredor non se podian bien lleer, e en fin de la dicha carta estaba escripto un nombre judiego $^{29}$.

Salvando la confusión entre águilas de alas abiertas y flores de lis, equivocación atribuible al pequeño tamaño de estos sellos, la descripción que ofrece este documento se ajusta perfectamente a la del escudo representado en la Sinagoga del Tránsito. Este escudo aparece en las placas escudadas a ambos lados del hejal, junto al escudo de su señor, Pedro I. También aparece en el friso de motivos vegetales que recorre la sala de oración separando cada sección del friso y, por parejas, en cada alfiz de las ventanas del muro oeste.

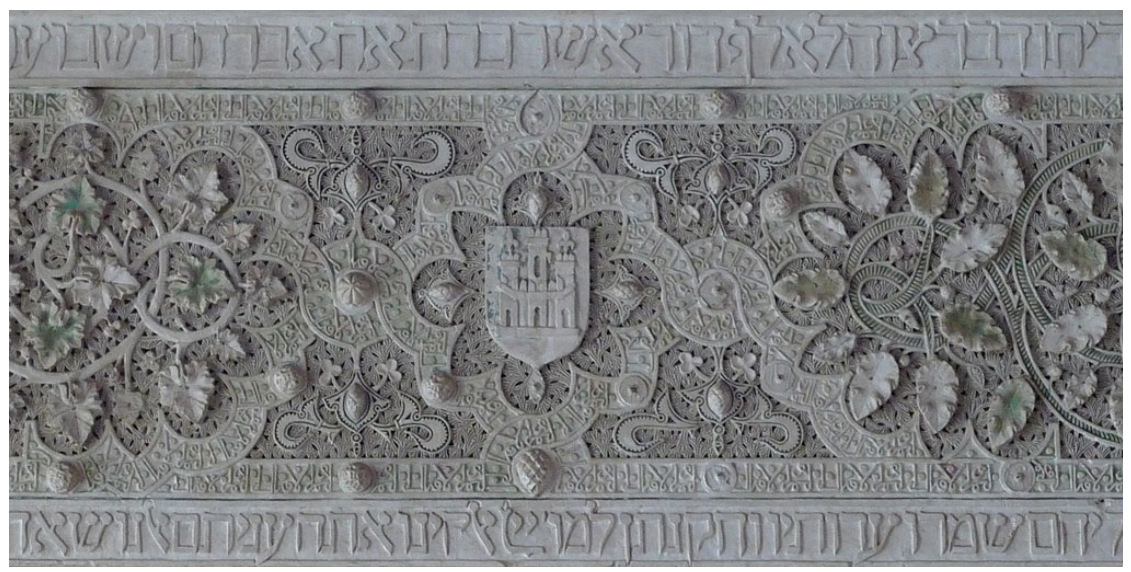

Fig. 4. Escudo atribuido a Samuel ha-Leví situado en el friso con motivos vegetales que recorre la sala de oración.

La población hispanojudía no podía formar parte de la nobleza, lo que no fue impedimento suficiente para que no fueran partícipes de ella, pues si no podían serlo de derecho, podían serlo en acto y apariencia. Muchos

\footnotetext{
${ }^{28}$ Madrid, Archivo Histórico Nacional, Sahagún. Reales, t. VII, núm. 258.

${ }^{29}$ Cantera Burgos y Millás Vallicrosa, Las inscripciones hebraicas, págs. 367368.
} 
miembros de las comunidades judías, independientemente de su nivel social, copiaron símbolos de la nobleza e, incluso, llegaron a crear linajes.

La utilización de símbolos tomados de la nobleza cristiana queda patente en algunos sellos de origen judío que tienen forma de escudo y contienen símbolos heráldicos, como la flor de lis. Sin embargo, estos símbolos no fueron imitados y reproducidos exclusivamente por judíos cortesanos, como podemos apreciar a partir de un sello encontrado en Lucena, que luce un maguén hatará, instrumento utilizado por el mohel para realizar la circuncisión, lo que parece indicar que su propietario fue una persona que se dedicaba de forma reconocida a esta ocupación.

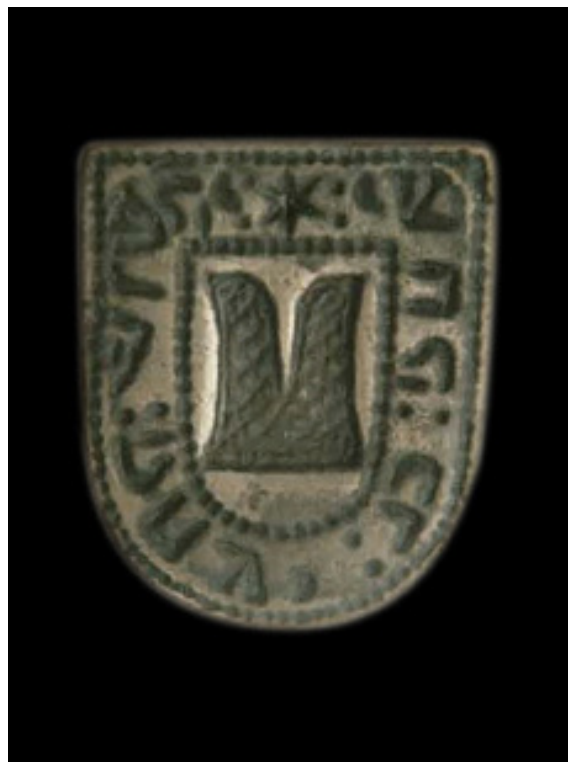

Fig. 5. Sello encontrado en Lucena que reproduce un maguén hatará propiedad de Juan Martínez Esterrona.

La presencia del escudo de Samuel en la sinagoga que fundó parece algo de lo más natural ya que Samuel se desenvolvía en ambientes cortesanos, pero el lema en árabe que acompaña los escudos parece querer insinuar algo que va más allá de las palabras que lo componen. Es fácil encontrar inscripciones en árabe inmersas en la decoración de palacios y conventos castellanos. El árabe ocupó un lugar importante dentro de la 
cultura castellana y formó parte de la identidad de la Corona de Castilla, aun así, es posible apreciar diferencias en el uso que del árabe se hace en la sinagoga. Es difícil imaginar a un rey castellano utilizando un lema en árabe de igual forma que resultaría contradictorio que el lema de la dinastía Nazarí estuviera escrito en latín en los muros de la Alhambra. Por esta razón la utilización de la epigrafía árabe por parte de Samuel ha-Leví traspasa la simple ornamentación puesto que desestima el hebreo para expresar este lema familiar. Entonces, ¿qué sentido podría tener un lema, escrito en árabe, junto al escudo de Samuel ha-Leví, dentro de un edificio cuya audiencia está compuesta por un público específicamente judío?

Los judíos hispanos se consideraron descendientes de aquellos que fueron deportados por Nabucodonosor o por Tito. Fundaron su seguridad e identidad en la identificación de la Península Ibérica con la Sefarad bíblica. Ellos eran los desterrados de Jerusalén que están en la Sefarad de Abdías, 20. Los hispanojudíos encontraron en tal identificación, que ya aparece en el Targum, su fundamentación bíblica, algo que todas las diásporas necesitan y no todas consiguen ${ }^{30}$.

Con el tiempo, a esta tradición bíblica se le fueron añadiendo otros matices para acabar identificando al-Ándalus con Sefarad. De esta forma surgieron nuevas obras literarias que dotaban a la diáspora de al-Ándalus de superioridad frente a las demás. Muestra de este origen orgulloso son algunos textos de la literatura hispano-hebrea, como el Kitab al-Muhadara wa-l-Mudakara de Mošé ibn Ezra (1055-después de 1135):

\section{Superioridad de la diáspora de al-Ándalus en lo tocante a la com- posición de poesía, de prosa y de epístolas hebreas, sobre otros, en respuesta a la quinta cuestión.}

Se debe a varias razones; la primera de ellas es su origen en las tribus de Judá y Benjamín, según narra el Libro al decir: «Y se levantaron los cabezas de familia de Judá y Benjamín, los sacerdotes y los levitas de toda la ciudad de Dios por su espíritu (Esd 1,5)» y también: «Y éstos son los hijos de la provincia que regresaron del cautiverio a quienes había deportado a Babilonia Nabucodonosor, rey de la misma, y que volvieron a Jerusalén y Judá, cada uno a su ciudad (Esd 2,1; Neh 7,6)». Estas

${ }^{30}$ José Ramón Ayaso MARTínEZ, «Antigüedad y excelencia de la diáspora judía en la Península Ibérica» Miscelánea de Estudios Árabes y Hebreos, sección hebreo 49 (2000) págs. 233-259: 238-239. 
categorías descritas son las gentes del «estrado honorable» (Templo), Jerusalén ciudad santa -sea construida y restablecida con premura- y sus aledaños. Se trata, pues, de los exiliados que salieron de Babilonia y de los otros que fueron a los países de los cristianos y hacia al-Ándalus, como narra el Libro:

«Y los desterrados de este ejército de los hijos de Israel que (hay desde) los cananeos hasta Sarfat y los desterrados de Jerusalén que están en Sefarad (Abd 1,20)». La nación se trasladó ya a Sarfat, «Francia», ya a Sefarad, «al-Ándalus» en la lengua de los árabes, como gentilicio de un hombre que se llamaba Andalisan, en época de rey antiguo Izdihaq. En la lengua de los cristianos Isfaniyya, gentilicio también de un hombre que era su señor bajo el dominio de los romanos, antes de los godos, cuyo nombre era Isfan. La sede de su reino era Isfuliyya, llamada con este nombre por el nombre de aquél. Y entre los antiguos era llamada Isfamwa.

Y no cabe duda de que las gentes de Jerusalén, a las que pertenece nuestra diáspora, eran las más conocedoras de la corrección en el idioma y en la transmisión de la Ley divina, respecto a los demás pueblos y villas ${ }^{31}$.

En esta obra, Ibn Ezra, explica que la superioridad de la diáspora de al-Ándalus radica principalmente en sus orígenes jerosolimitanos. Sus miembros provenían de las tribus de Judá y Benjamín, y de los sacerdotes y Levitas del Templo, de los que vendría el linaje de Samuel ha-Leví. Por otro lado, Ibn Ezra, usa también la figura de Nabucodonosor para dejar constancia de que los miembros de la diáspora de al-Ándalus descienden de la élite cultural que fue deportada a Babilonia.

Otro ejemplo de esta tradición genealógica nos lo ofrece Abraham Ibn Daúd (c.1110-1180) en su Séfer ha-Cabalá, al explicarnos los orígenes de Yehudá ha-Nasí Ibn Ezra:

Sus antepasados eran de una de las familias principales de Granada, herederos de autoridad y cargos en cada generación en el reinado de Badis ben Jabus, rey beréber y en el de Jabus, su padre. Según una tradición que había en la comunidad de Granada, ellos habían sido ciudadanos de Jerusalén, la Ciudad Santa, descendientes de Judá y Benjamín, y no de pueblos o ciudades desmilitarizadas. Pero R. Yehudah ha-Nasí y su padre y sus tíos, que fueron cuatro oficiales: R. Yisjaq el grande, el segundo R.

${ }^{31}$ Mošé Ibn 'Ezra, Kitab al-muhadara wal-mudakara, ed. y trad. Montserrat Aвumalham Mas (Madrid 1986) vol. 2, págs. 59-60. 
Moseh, el tercero R. Yehudah y el cuarto R. Yosef, todos ellos eran de descendencia real y de la nobleza ${ }^{32}$.

Abraham Ibn Daúd también mira hacia Jerusalén a la hora de establecer un linaje pero, a diferencia de Mošé Ibn Ezra, no se limita a la geografía, sino que establece una línea genealógica con la realeza y nobleza de Israel. Siguiendo esta tradición, es posible sugerir que un lema escrito en árabe junto a los escudos de Samuel, en una sinagoga sobre suelo cristiano, pretende afirmar los orígenes andalusíes de la familia ha-Leví Abulafia, para así entroncar el linaje familiar con esta tradición genealógica, que a través de al-Ándalus asienta sus orígenes en la ciudad de Jerusalén y en el prestigio, e incluso nobleza, de los que fueron sus habitantes.

La familia Abulafia (del árabe Abu l-Afiya 'padre poseedor de buena salud'), de origen andalusí, gozó de gran influencia en diferentes lugares y épocas a lo largo de la Edad Media. La rama más destacada de la familia fue precisamente la afincada en Toledo, cuyos miembros se hacían llamar al-Lawí Abulafia ${ }^{33}$, que es una arabización de ha-Leví. Tanto el epitafio atribuido a Meír ha-Leví ${ }^{34}$, padre de Samuel, como en el del propio Samuel ha-Leví podemos encontrar este nombre arabizado:

Es una Piedra de Toque (o Probada) y bajo ella atesoraste un justo probado. Soportó la vara de la corrección y de los caminos de Dios no se apartó. Aceptó los sufrimientos por amor, gustó de los castigos con magnanimidad cuando estalló la ira de Yahveh contra la casa de Levi y la colmó de desprecio; su señor [Pedro I] lo puso en el lugar donde estaban encerrados los presos del rey. Allí lo sometió a ley y juicio y allí lo sometió a prueba [del tormento]. Y allí clamó Yahveh, «iSamuel, Samuel!» y subióle hacia sí, a la altura, en la casa de Dios, al gran jefe R. Samuel, príncipe de Dios. Samuel se preparó en un principio, y tornó Yahveh a llamar por tercera vez a Samuel, capullo de la tribu de Levi

${ }^{32}$ Abraham Ibn Daúd, Sefer ha-Qabbalah (Libro de la tradición), ed. y trad. Lola FERre CANo (Barcelona 1990) pág. 105.

${ }^{33}$ Leah Bornstein-Makovetsky, «Abulafia Family», en Encyclopedia of Jews in the Islamic World, ed. Norman A. Stillman. Vol.1 (Leiden-Boston 2010) págs. 42-44.

${ }^{34}$ En el epitafio atribuido al padre de Samuel ha-Leví también aparece este nombre arabizado; Cantera Burgos y Millás Vallicrosa, Las inscripciones hebraicas, págs. 147-149. 
y su rama más alta y flor de su gloria esplendorosa, selecto y de bello aspecto de hermosos ojos y con doble aliento en su espíritu. Tal fue R. Samuel ha-Leví descanse en gloria, hijo del honorable R. Meir ha-Levi que el espíritu divino lo guíe, apellidado Abulafia. Falleció en el mes de marheswan ${ }^{35}$.

Podemos observar que en las inscripciones de tumbas de otros miembros de esta familia también está presente la arabización de ha-Leví, escrita en aljamía, es decir, árabe con caracteres hebreos: בן אל-לאוי (ben al-Lawí). La arabización del nombre familiar es intencionada, puesto que, generalmente, tras el nombre del progenitor del difunto, se coloca haLeví seguido de al-Lawí, como por ejemplo en este epitafio:

Guárdase en esta sepultura a R. Isaac ha-Levi, hijo del preclaro maestro R. Todros ha-Levi -descanse en el Edén- ben al-Lawí, El cual falleció el 15 de Tébet del 5102 de la Creación (25 de diciembre de 1341), ¡Dios en su misericordia, tenga piedad de él! $!^{36}$

El prestigio que aporta el origen andalusí parece estar detrás de la arabización de ha-Leví, en sintonía con el sentido que propongo para la inscripción árabe de la sinagoga. Muchas lápidas de miembros de la familia ha-Leví Abulafia no sólo resaltan el origen andalusí en sus epitafios, sino que exhiben también un lenguaje grandilocuente, que alude al linaje del que provienen. Esta exhibición orgullosa y ostentosa puede llevarnos a pensar que muchos de los miembros de esta ilustre familia se sentían reconocidos en las tradiciones que conectan el origen andalusí con el de los «nobles» de Jerusalén.

A pesar del contexto cultural y social cristiano de Castilla, hay elementos de la cultura árabe que permanecieron entre las comunidades judías castellanas. La cultura judía andalusí no desapareció con la llegada en 1147 de los almohades. La élite cultural judía trabajó y se aseguró de llevarla a lugar seguro para restablecerla en sus nuevas comunidades ya en territorio cristiano ${ }^{37}$.

${ }^{35}$ Cantera Burgos y Millás Vallicrosa, Las inscripciones hebraicas, pág. 159.

${ }^{36}$ Cantera Burgos y Millás Vallicrosa, Las inscripciones hebraicas, pág. 110.

${ }^{37}$ Jane Satlow Gerber, «The World of Samuel Halevi: Testimony from the El Transito Synagogue of Toledo» en The Jew in Medieval Iberia, 1100-1500, ed. Jonathan RAY (Boston 2012) págs. 33-59: 36 y 42. 
Entre los judíos de Toledo se puede percibir una admiración profunda por la cultura árabe. Esto se manifiesta en el uso de la lengua árabe en diversos contextos, en la conservación de las tradiciones literarias de al-Ándalus, de origen árabe, en el gusto por la estética hispanoárabe, como vemos en la sinagoga e, incluso, en la fascinación por lo que representa el refinamiento del ideal de la vida andalusí en contraposición a la sobriedad castellana ${ }^{38}$. En mi opinión, el mantenimiento por parte de sectores de la élite judía de Toledo de esta herencia cultural y de un imaginario sobre al-Ándalus, les dotaba de un origen prestigioso y un linaje aristocrático, que les otorgaba un estatus nobiliario simbólico con el que desenvolverse entre iguales con las élites castellanas.

En el caso de la Sinagoga del Tránsito, Samuel ha-Leví, a través de su escudo, se sirve de la heráldica de origen cristiano y de las inscripciones árabes como seña de identidad ${ }^{39}$, a la vez que pretende entroncar con una tradición que, como ya hemos visto, lo dotaba de un linaje de calidad que justificaba su estatus social, autoridad y prestigio.

Samuel ha-Leví no fue el único miembro de las élites judías que usó esta tradición para la construcción de un linaje. Otros judíos ya habían hecho uso de ella. Él es un eslabón más en la cadena de transmisión de esta tradición. Tras él, otros aristócratas harían uso de de ella a lo largo de la historia. Un ejemplo posterior lo encontramos en el siglo XVI, en el libro de Salomón Ibn Verga (c. 1460-1554), La vara de Judá, donde, a propósito de la familia de origen sevillano Abravanel, el sabio Tomás narra al rey sus orígenes regios:

${ }^{38}$ Ángel SÁenz-BADILLOS, «La sociedad de Toledo en el siglo XIII vista por los poetas judíos» en La sociedad medieval a través de la literatura hispanojudía, eds. Ricardo IzQuierdo Benito y Ángel SÁenz-Badillos (Cuenca 1998) págs. 199-238: 207.

${ }^{39}$ A comienzos del siglo XIV la heráldica comenzó a acompañar a las inscripciones que decoraban las fachadas. En su inicio, de manera discreta, como ocurre en el Palacio de Comares (Alhambra), o el de la Montería (Reales Alcázares de Sevilla), pero con el tiempo estos elementos se fusionaron en las construcciones cristianas de la baja Edad Media. En algunos edificios de la Edad Media tardía las inscripciones heráldicas son las únicas que aparecen en las fachadas. Este es un fenómeno exclusivo de la Península Ibérica; Juan Carlos RuIz SouzA, «Architectural Languages, Functions, and Spaces: The Crown of Castile and Al-Ándalus», Medieval Encounters 12:3 (2006) págs. 360-387: 368-369. 
Respondió Tomás:

-Se alegrará nuestro señor cuando hable con él, tanto más cuanto él es de estirpe regia.

Replicó el rey:

-Eso es falso porque, según tenemos entendido, toda la estirpe real de Judah fue extinguida cuando atacó Nabucodonosor, pues temió que se rehiciera el pueblo contando con una estirpe de la realeza.

Tomás contestó:

-Sepa nuestro señor que, cuando vino Nabucodonosor contra Jerusalén, otros reyes poderosos acudieron para ayudarle por el temor que le tenían, pues dominaba con su poderío sobre las naciones del mundo, y también por el odio que sentían contra los judíos por su ley. A la cabeza de aquéllos llegó el rey Hispano, del cual el reino de Sefarad tomó su nombre Hispania. Con él fue su yerno, llamado Pirro, de los príncipes de Grecia; Pirro e Hispano asolaron y desbarataron la nación de los judíos con todo su poder y bravura, y también tomaron Jerusalén. El rey Nabucodonosor, cuando vio su ayuda, les dio parte del botín y en los cautivos, a la usanza de los reyes. También ha de saber nuestro señor que en Jerusalén había tres recintos amurallados de norte a sur; que desde la muralla de la ciudad de la parte de occidente hasta el primer recinto habitaban todos los artesanos, predominando los trituradores de aromas, pues eran precisos para el culto del Templo de quienes el profeta había dicho: «Gemid, habitantes del mortero». Del primer recinto al segundo habitaban todos los escolares del Libro y los mercaderes; porque los sabios necesitaban más de los mercaderes que los mercaderes de ellos. Es la razón de que el comerciante no entienda la necesidad de la sabiduría, en cambio los sabios entienden la necesidad del dinero. Desde el segundo recinto al tercero vivían los de estirpe real, la familia de David, y los sacerdotes encargados del culto.

»Cuando Jerusalén fue repartida entre aquellos reyes, Nabucodonosor tomó para si dos recintos y los restantes de las provincias, se los llevó a Persia y Media. El tercer recinto lo entregó a Pirro e Hispano. El referido a Pirro tomó unas naves y llevó a todos los cautivos a la antigua Sefarad, esto es, a Andalucía, y a la ciudad de Toledo; desde allí se extendieron porque eran numerosos y el país no podía contenerlos a todos. Algunos que eran de prosapia real, se dirigieron a Sevilla y desde ésta marcharon a Granada.

»Cuando sucedió la destrucción del segundo Templo había en Roma un césar que imperaba sobre todo el mundo. Tomó de Jerusalén cuarenta mil familias del linaje de Judah -de Jerusalén y de otras ciudades- y diez mil del de Benjamín y los sacerdotes, enviándolas a Sefarad, que formaba 
parte de su imperio por aquellos días. La mayoría de los del linaje de Benjamín y los sacerdotes, y unos pocos de los hijos de Judah, marcharon a Francia (Sarfat), de suerte que los judíos que están hoy en tu reino son de estirpe real y una gran parte de ellos, del linaje de Judah. Por tanto, ¿cómo se maravilla nuestro señor de hallar una familia que descienda de David ${ }^{40}$

Es significativo que, en la obra anteriormente citada de Abraham Ibn Daúd, la ciudad de Granada aparece mencionada como un lugar en el que esta tradición genealógica estaba muy presente y, como vemos en el texto de Salomón Ibn Verga, Granada y Sevilla son utilizadas como dos fuertes iconos dentro de esta tradición, que conectaba los orígenes sefardíes con la ciudad de Jerusalén a través de al-Ándalus. Sevilla era una ciudad presente en la vida de Samuel, parte de la familia ha-Leví Abulafia residía en la ciudad, allí también tenía negocios y fue allí donde fue apresado por orden de Pedro I. Sevilla y Granada parecen cumplir un rol destacado en esta tradición. Ambas ciudades también ocupan un importante lugar en la obra Omer ha-Šijeha, un comentario al Libro de Proverbios, en el que la familia Gavison, asentada en Argelia, realiza una línea genealógica a través de varias generaciones para establecer los orígenes fundacionales de la familia en las ciudades de Granada y Sevilla ${ }^{41}$.

\section{Conclusión}

Samuel ha-Leví, aunque judío, fue un cortesano en todo el sentido del término. Sus acciones políticas están en sintonía con las de otros cortesanos cristianos. Cortesanos que, en general, pertenecían a la nobleza, potenciaban su honor y el renombre de su casa con la fundación de edificios religiosos, o con la construcción de palacetes y casas señoriales, que servían de estandarte y emblema de la grandeza y nobleza de sus familias. Samuel ha-Leví construyó una imagen pública que legitimaba su posición dentro de la sociedad toledana del siglo XIV. Su sinagoga es un elemento principal dentro de esta imagen que él quiso mostrar.

${ }^{40}$ Salomón Ibn Verga, Sefer Šebet Yehudah (La vara de Yehudah), trad. M. ${ }^{a}$ José CANo Pérez (Barcelona 1991) págs. 48-49.

${ }^{41}$ Esperanza Alfonso CARro, «From Al-Ándalus to North Africa: The Lineage and Scholarly Genealogy of a Jewish Family», en The Jew in Medieval Iberia, 1100-1500, ed. Jonathan RAY (Boston 2012) págs. 395-419. 
Samuel ha-Leví, en su sinagoga, hizo uso de una estética basada en el poder en la que él se percibía a sí mismo como un descendiente de la realeza de Israel. A través de la sinagoga y sus inscripciones buscó ser visto por su comunidad como un hombre rico, poderoso, sabio y descendiente de un linaje nobiliario que hundía sus raíces en la ciudad de Jerusalén.

Al igual que las obras literarias citadas en este trabajo, la figura de Samuel ha-Leví y su sinagoga sirvieron como transmisoras de símbolos y tradiciones que, posteriormente, otros judíos poderosos continuaron usando y transmitiendo. Tradiciones y símbolos que establecían una línea genealógica que muchas familias de la élite judía tomaron como propias, para establecer en la Jerusalén bíblica los orígenes fundacionales de sus linajes.

Recibido: 18/01/2016

Aceptado: 03/05/2016 